\title{
Kierownictwo zlecającego w zakresie zatrudnienia cywilnoprawnego oraz samozatrudnienia
}

\section{Uwagi wstępne}

Y ierownictwo zlecającego rzadko jest poddawane analizom w piUśmiennictwie prawniczym ${ }^{1}$. Wiele zagadnień z zakresu kierownictwa zlecającego nie zostało dotychczas rozpoznanych. To uzasadnia niniejsze opracowanie.

Kierownictwo zlecającego w zakresie zatrudnienia cywilnoprawnego oraz samozatrudnienia ma duże znaczenie normatywne oraz praktyczne. Z punktu widzenia normatywnego chodzi o podstawy prawne kierownictwa zlecającego, relację tego pojęcia do pojęcia ",kierownictwo pracodawcy". Aspekt praktyczny to stosowanie czynności kierowniczych przez zlecającego wobec wykonawcy pracy (usług). Praktyczne znaczenie ma porównanie form kierownictwa zlecającego $\mathrm{z}$ formami kierownictwa pracodawcy.

\section{Podstawy prawne kierownictwa zlecającego}

Wyjściowe znaczenie ma wskazanie podstaw prawnych kierownictwa zlecającego. O kierownictwie zlecającego jest mowa w art. 5b ust. 1 pkt. 2 ustawy o podatku dochodowym od osób fizycznych (dalej oznaczona

* Prof. dr hab., Zakład Prawa Pracy, Wydział Prawa, Administracji i Ekonomii Uniwersytetu Wrocławskiego.

${ }_{1}$ Z. Kubot, Kierownictwo zlecajacego jaki pojęcie prawne, [w:] Z zagadnień wspótczesnego prawa pracy. Księga jubileuszowa Profesora Henryka Lewandowskiego, Warszawa 2009, s. 121128; idem, Kierownictwo pracodawcy, [w:] Kształtowanie warunków pracy przez pracodawcę. Możliwości i granice, Difin, Warszawa 2011, s. 117-124; T. Duraj, Wybrane problemy pracowniczego podporzadkowania jako konstytutywnej cechy stosunku pracy, [w:] Wspótczesne problemy prawa pracy i ubezpieczeń społecznych, red. L. Florek, Ł. Pisarczyk, Warszawa 2011, s. 159-160. 
w skrócie jako ustawa o p.d.o.f.). W przepisie tym stanowi się o wykonywaniu czynności pod kierownictwem oraz w miejscu i w czasie wyznaczonym przez zlecającego.

Czy powyższy przepis stanowi podstawę ustawową kierownictwa zlecającego tego rodzaju co art. $22 \S 1$ k.p. w odniesieniu do kierownictwa pracodawcy? Na to pytanie należy udzielić odpowiedzi przeczącej. Artykuł $22 \S 1$ k.p. wprowadza kierownictwo pracodawcy jako konstytutywna, konstrukcyjną właściwość stosunku pracy ${ }^{2}$. Artykuł 5b ust. 1 pkt 2 u o p.d.o.f. nie jest przepisem, który ustanawia kierownictwo zlecającego jako właściwość stosunków cywilnoprawnych o świadczenie usług. Artykuł ten jest przepisem prawa podatkowego mającym znaczenie dla wyznaczania zakresu pojęcia działalności gospodarczej i rozgraniczenia tego pojęcia od innych rodzajów działalności osób fizycznych. Artykuł 5b ust. 1 pkt 2 u o p.d.o.f. wskazuje jedynie na dopuszczalność kierownictwa zlecającego w zakresie wykonywania czynności w ramach umów cywilnoprawnych przez osoby fizyczne.

\section{Kierownictwo kontraktowe}

Kierownictwo zlecającego uznane za dopuszczalne $\mathrm{w}$ art. 5b ust. 1 ustawy o p.d.o.f. może mieć podstawę w umowie cywilnoprawnej. Umowa cywilnoprawna może zawierać postanowienie uprawniające zlecającego do udzielania wskazówek czy instrukcji wykonawcy zlecenia. Będzie to podstawa stosowania przez zlecającego wymienionych czynności kierowniczych.

Praktycznie nie wydaje się możliwe, aby umowa cywilnoprawna zawierała postanowienie określające ogólne uprawnienia zlecającego do kierowania pracą wykonawcy usług czy postanowienie o wykonywaniu przez zleceniobiorce pracy pod kierownictwem zlecającego. Takie postanowienia mogą bowiem rodzić obawę o uznanie umowy cywilnoprawnej za umowę pozorną ze względu na ogólne, bliżej nieokreślone uprawnienie zlecającego do kierowania pracą zleceniobiorcy.

W praktyce najczęściej jest tak, że umowa cywilnoprawna o świadczenie usług nie zawiera jakiegokolwiek postanowienia o formach kierowania pracą wykonawcy usług przez zlecającego. Nie oznacza to, że umowa cywilnoprawna nie stanowi podstawy uprawnień kierowniczych zlecającego. Zgodny zamiar stron co do kierownictwa zlecającego może zostać wyrażony nie tylko w samej treści umowy, ale także w jakikolwiek sposób poza tą umową.

\footnotetext{
${ }^{2}$ Por. wyrok z dnia 25 listopada 2005 r. I UK 68/05, Wokanda 2006/4/26.
} 
W orzecznictwie wskazano, że „konieczne jest rozważenie wszelkich aspektów prawnych dotyczących zgodnego, a w konsekwencji skutecznego oświadczenia woli stron stosunku prawnego dotyczących jego cech istotnych. Cechy te obejmują wspólnie uzgodnione elementy faktyczne i prawne kształtujące treść umowy (essentialia negotii), które kreują charakter prawny nawiązanego i realizowanego stosunku prawnego" 3 .

Zawarcie umowy cywilnoprawnej o świadczenie usług w określonej strukturze organizacyjnej może zostać uznane za uzgodnienie między stronami form kierowania zlecającego, które są niezbędne dla realizacji kontraktu w sposób odpowiadający jego woli i potrzebom. Przykładem mogą tu być kontrakty cywilnoprawne zawierane $\mathrm{z}$ menedżerami średnich i niższych szczebli w spółkach kapitałowych, a także kontrakty cywilnoprawne lekarzy oraz pielęgniarek o udzielanie świadczeń zdrowotnych w przedsiębiorstwie podmiotu leczniczego.

\section{Zróżnicowanie kierownictwa zlecającego}

Kierownictwo zlecającego jest zróżnicowane zależnie od rodzaju i właściwości czynności zleconych wykonawcy, woli zlecającego oraz jego potrzeb. Wykonanie zleconych czynności w sposób odpowiadający potrzebom i woli zlecającego może wymagać ich konkretyzowania przez zlecającego. Przykładowo dotyczy to czynności pielęgniarki oraz czynności lekarza na oddziale szpitalnym. Jeżeli z pielęgniarką czy lekarzem zostanie zawarta umowa cywilnoprawna o wykonywanie określonego rodzaju czynności na oddziale szpitalnym, to nieodzowne będzie kierownictwo zlecającego w zakresie tych czynności. Kierownictwo to nie może obejmować poleceń wydawanych przez przełożonego.

Nie można przyjmować, że praca pielęgniarki oraz lekarza na oddziale szpitalnym będzie, odbywać się bez jakiegokolwiek kierownictwa. Pracą lekarza zatrudnionego, jak też samozatrudnionego na oddziale szpitalnym kieruje w jakimś zakresie oraz formie ordynator, a pracą pielęgniarki pielęgniarka oddziałowa. Oddział szpitalny jest komórką organizacyjną kierowaną przez ordynatora, koordynatora lub kierownika oddziału .

Pracą pielęgniarek na oddziale kieruje pielęgniarka oddziałowa.

${ }^{3}$ Z uzasadnienia wyroku sądu najwyższego z dnia 27 lutego 1998 r. I PPN 532/97, OSNAPiUS 1981.

${ }^{4}$ Szerzej Z. Kubot, Nieordynatorskie systemy prowadzenia oddziałów szpitalnych, Klemar, Wrocław 2007, s. 45-87. 


\section{Szczególna podstawa prawna kierownictwa zlecającego}

Szczególną podstawę kierownictwa zlecającego stanowi art. 41 ust. 1 ustawy z dnia 8 września 2006 r. O Państwowym Ratownictwie Medycznym ${ }^{5}$, zgodnie z którym akcją prowadzenia medycznych czynności ratunkowych kieruje wyznaczony przez dyspozytora medycznego kierujący.

W ramach kierowania akcją prowadzenia medycznych czynności ratunkowych kierujący może wydawać członkom zespołu ratownictwa medycznego polecenia. W sytuacji wykonywania przez ratownika medycznego pracy (usług) na podstawie umowy cywilnoprawnej polecenia kierującego akcją prowadzenia medycznych czynności ratunkowych są czynnościami kierowniczymi zlecającego (kontrahenta umowy cywilnoprawnej zawartej z ratownikiem medycznym). W sytuacji wykonywania przez ratownika medycznego pracy na podstawie umowy o pracę polecenia kierującego akcją prowadzenia medycznych czynności ratunkowych są poleceniami przełożonego $\mathrm{w}$ rozumieniu art. $100 \S 1 \mathrm{k} . \mathrm{p}$.

Poza art. 41 ust. 1 ustawy z dnia 8 września 2006 r. O Państwowym Ratownictwie Medycznym podstawą poleceń wydawanych przez kierującego akcją prowadzenia medycznych czynności ratunkowych ratownikom zaangażowanym na podstawie kontraktu cywilnoprawnego, może być także ten kontrakt. $\mathrm{W}$ umowach cywilnoprawnych zawieranych z ratownikami medycznymi zamieszczone jest postanowienie nakładające obowiązek natychmiastowego wykonania poleceń kierownika zespołu ratownictwa medycznego.

\section{Formy kierownictwa zlecającego}

Jak zaznaczono formy kierownictwa zlecającego zależą od rodzaju zleconych czynności oraz woli i potrzeb zlecającego. Mogą to być takie czynności jak w szczególności wskazówki, fachowe wskazówki, zlecenia, instrukcje, opinie, akceptacja, rady, sugestie. Kierownictwo zlecającego może też wyrażać się w planowaniu (w tym w planowaniu pakietu zadań oraz podzadań $w$ ramach projektów realizowanych przez wykonawcę umowy cywilnoprawnej), koordynowaniu, nadzorze oraz kontroli.

Stosowanie wymienionych wyżej czynności będzie zależeć od potrzeb zlecającego, jego wyboru czynności uznanych w danej sytuacji za właściwe dla kierowania pracą wykonawcy czynności. W określonej umowie cywilnoprawnej czy w określonych warunkach jej realizacji pewne czynności podejmowane przez zlecającego $\mathrm{w}$ ramach jego kierownictwa mogą mieć charakter typowy lub standardowy. Inne mogą być podejmowane rzadko czy tylko okazjonalnie

\footnotetext{
${ }^{5}$ DzU, 2006, nr 191, poz. 1410.
} 


\section{Kierownictwo zlecającego a kierownictwo pracodawcy}

Kierownictwo zlecającego wymaga porównania do kierownictwa pracodawcy. Jest to kwestia form realizowania tych dwóch rodzajów kierownictwa. Specyfiką kierownictwa pracodawcy jest prawo wydawania poleceń mające podstawę ustawową w art. $100 \S 1$ k.p.

Na podstawie art. $22 \S 1$ k.p. pracodawca może kierować pracą pracownika nie tylko przez polecenia, ale także przez inne czynności konkretyzujące obowiązki pracownika ${ }^{6}$. Czynnościami konkretyzującymi obowiązki pracownika mogą być wskazówki, fachowe wskazówki, instrukcje, zalecenia, sugestie, rady. Polecenie jest tylko jednym z wielu sposobów konkretyzacji obowiązków wykonawcy pracy ${ }^{7}$. Jak zaznaczył Z. Masternak, konkretyzacja obowiązków kontrahenta umowy może nastąpić przez innego rodzaju wypowiedzi - niebędące w ogóle dyrektywami lub będące dyrektywami „niestanowczymi” - w postaci zalecenia, rady, zlecenia zadania, propozycji, wskazówki ${ }^{8}$.

Zestawienie czynności stosowane $\mathrm{w}$ ramach kierownictwa zlecającego $\mathrm{z}$ czynnościami stosowanymi $\mathrm{w}$ zakresie kierownictwa pracodawcy wykazuje, że w znacznej, a może nawet przeważającej mierze są to czynności tego samego rodzaju. Różnica między kierownictwem zlecającego a kierownictwem pracodawcy polega na niedopuszczalności stosowania poleceń w pierwszym typie kierownictwa

Różnica między kierownictwem zlecającego a kierownictwem pracodawcy polega też na tym, że to pierwsze może występować w niektórych stosunkach zatrudnienia oraz samozatrudnienia9, a drugie stanowi konstytutywną cechę stosunku pracy.

\section{Koncepcje kierowania w ramach stosunków zatrudnienia cywilnoprawnego oraz samozatrudnienia}

Kierownictwo zlecającego może być użyteczne dla realizowania koncepcji kierowania (zarządzania) w sytuacjach wykonywania przez osoby fizyczne pracy na podstawie umów cywilnoprawnych. Będą to alternatywne koncepcje kierowania wobec kierowania opartego na kierownictwie pracodawcy.

${ }^{6}$ Trafne jest spostrzeżenie Sądu Najwyższego, że określenie „stosować się do poleceń pracodawcy" (art. $100 \S 1$ k.p.) jest węższe niż zwrot "pod jego kierownictwem” (art. 22 $\S 1$ k.p.).

7 Z. Masternak, Obowiazzek pracowniczej staranności, Warszawa 1977, s. 78.

8 Ibidem.

${ }^{9}$ Por. Z. Kubot w: Z. Kubot, T. Kuczyński, Z. Masternak, H. Szurgacz, Prawo pracy. Zarys wykładu, Warszawa 2011. 
Koncepcja kierowania w kategoriach kierownictwa zlecającego może być opracowana i realizowana $\mathrm{w}$ zakresie oddziałów szpitalnych $\mathrm{w}$ razie wykonywania w nich pracy przez lekarzy oraz pielęgniarki na podstawie umów cywilnoprawnych. Koncepcja takiego kierowania może być stosowana w zakresie pracy tzw. kontraktowych lekarzy. Wobec pozostałych lekarzy i pielęgniarek zatrudnionych na podstawie umów o pracę będzie stosowana koncepcja kierowania oparta na kierownictwie pracodawcy.

Koncepcje kierowania przy wykorzystaniu kierownictwa zlecającego mogą być stosowane w podmiotach leczniczych zatrudniających na podstawie umów cywilnoprawnych nauczycieli akademickich uczelni medycznej. Artykuł 92 ustawy od działalności leczniczej przewiduje umowę cywilnoprawną jako alternatywną wobec umowy o pracę podstawę zatrudnienia nauczycieli akademickich uczelni medycznej ${ }^{10}$.

Koncepcja kierownictwa zlecającego może znajdować zastosowanie w spółkach kapitałowych dla zapewnienia jednolitości kierownictwa nie tylko w poszczególnych spółkach, ale także jednolitości kierownictwa w całej grupie kapitałowej. Wykonawcy usług cywilnoprawnych zaangażowani przez spółkę zależną mogą być poddawani pewnym formom kierowania ze strony osób reprezentujących spółkę.

\section{Kierownictwo zlecającego a pozycja stron stosunków cywilnoprawnych}

Kierownictwo zlecającego wymaga analizy w aspekcie pozycji stron obligacyjnych stosunków cywilnoprawnych. Równorzędność stanowić ma właściwość stosunku cywilnoprawnego, odróżniając ten stosunek od stosunku pracy.

W piśmiennictwie zaznaczono, że zasada równorzędności „przenika” całe prawo cywilne, mimo że nie została wyrażona wprost w konkretnym przepisie iuris cogentis ${ }^{11}$. W uchwale składu 7 sędziów z dnia 22 maja Sąd Najwyższy przyjął, że cechą konstytutywną stosunku obligacyjnego jest równorzędność obu jego stron i jedna ze stron nie może zostać podporządkowana całkowicie drugiej ${ }^{12}$.

Zasadę równorzędności podmiotów stosunków cywilnoprawnych akcentuje się w komentarzach do art. 1 k.c. Przykładowo K. Pietrzykowski

${ }^{10}$ Szerzej Z. Kubot, Zatrudnienie nauczycieli akademickich uczelni medycznej w szpitalu klinicznym jako zatrudnienie szczególne, [w:] Z aktualnych zagadnień Prawa Pracy i Zabezpieczenia Społecznego. Księga jubileuszowa Profesora Waleriana Sanetry, red. B. Cudowska, J. Iwulski, Tymida, Białystok 2013, s. 210-214.

${ }^{11}$ J. Guść, O właściwości (naturze) stosunku prawnego, „Państwo i Prawo” 1997, nr 4, s. 19.

12 OSNCP 1992, nr 1, poz. 1. 
zaznacza, że pierwszą cechą prawa cywilnego jest równorzędność podmiotów stosunku prawnego, tzn. brak władczego podporządkowania ${ }^{13}$.

Ustalenia dotyczące kierownictwa zlecającego w odniesieniu do równorzędności stron stosunku cywilnoprawnego mogą być różne w zależności od tego jak będzie rozumiana równorzędność stron tego stosunku prawnego i jak będzie kwalifikowane w aspekcie władztwa kierowniczego kierownictwo zlecającego.

Jeżeli władztwo kierownicze będzie rozumiane jako ustawowo określone uprawnienie do stanowczego konkretyzowania obowiązków kontrahenta przez określony ustawowo rodzaj czynności, to kierownictwo zlecającego inaczej niż kierownictwo pracodawcy nie należy do tak ujętego władztwa kierowniczego. Kierownictwo zlecającego nie narusza tu równorzędności stron stosunku cywilnoprawnego. Pozycja zlecającego w umowie cywilnoprawnej różni się od pozycji pracodawcy w stosunku pracy ${ }^{14}$.

Na powyższym wyjaśnieniu nie można poprzestać z tego względu, że czynności podejmowane $\mathrm{w}$ ramach kierownictwa zlecającego mają pewną moc wiążącą. Dotyczy to takich czynności jak: wskazówki, fachowe wskazówki, instrukcje.

Czy pewna moc wiążąca wymienionych czynności oznacza, że kierownictwo zlecającego jest władczym kierownictwem podważającym równorzędność prawną stron stosunku cywilnoprawnego pracy? Na to pytanie należy odpowiedzieć przecząco.

Wiadomo, że w stosunku zlecenia dopuszczalne są wskazówki zlecającego mające dla wykonawcy moc wiążąca, wskazówki o charakterze stanowczym ${ }^{15}$. Tego rodzaju wskazówek zlecającego nie kwalifikuje się jako formy władztwa kierowniczego podważającego równorzędność stron obligacyjnego stosunku cywilnoprawnego.

Zastane kwalifikacje wskazówek zlecającego w aspekcie równorzędności stron stosunku zlecenia oznaczają że kierownictwo zlecającego nie podważa równorzędności stron stosunku cywilnoprawnego.

Powyższa prawna kwalifikacja kierownictwa zlecającego nie wyklucza innych kwalifikacji. Do takich należeć będzie kwalifikacja kierownictwa zlecającego $\mathrm{w}$ aspekcie pojęcia władzy w najogólniejszym znaczeniu jako zdolności wywoływania skutków ${ }^{16}$ czy w aspekcie władzy

${ }^{13}$ K. Pietrzykowski w: Kodeks cywilny, t. I, Komentarz do artykułów 1-44911, red. K. Pietrzykowski, wyd. 4, Warszawa 2005, s. 34.

${ }^{14}$ O pozycji stron stosunku pracy szerzej Z. Kubot, Pozycja prawna stron w umownym stosunku pracy, Ossolineum, Wrocław 1978, s. 33 do 133.

15 Szerzej o różnych wskazówkach zlecającego por. Z. Kubot, Kontrakty menedżerskie średniej kadry kierowniczej, Klemar, Wrocław 1999, s. 92-94.

${ }^{16} \mathrm{~W}$ takim najogólniejszym znaczeniu władza stanowi też przedmiot rozważań zawartych w pracy J. Scotta, Władza, Sic!, Warszawa 2001, s. 7 i nast. 
organizacyjnej $\mathrm{w}$ ujęciu teorii zarządzania ${ }^{17}$. Czynności podejmowane w ramach kierownictwa zlecającego jako czynności skutecznie wyznaczające zachowanie wykonawcy określonej pracy mogą być uznawane jako rodzaj władzy w najogólniejszym znaczeniu czy też rodzaj władzy zarządzania $\mathrm{w}$ rozumieniu teorii organizacji zarządzania. Takie kwalifikacje kierownictwa zlecającego nie podważają prawnej zasady równorzędności stron stosunku cywilnoprawnego.

\section{Kierownictwo zlecającego a ukryte kierownictwo pracodawcy}

W praktyce może być tak, że kierownictwo zlecającego wykorzystywane będzie dla ukrycia kierownictwa pracodawcy. Stanie się tak wówczas, gdy zlecający faktycznie wydawać będzie wykonawcy zleconych czynności polecenia konkretyzujące te czynności. Wydaje się, że sytuacje takie nie będą należały do rzadkości.

Posługiwanie się przez zlecającego poleceniami wobec wykonawcy pracy, oznacza że stosunek cywilnoprawny staje się faktycznie stosunkiem pracy, a zatrudnienie cywilnoprawne lub samozatrudnienie - zatrudnieniem pozornym.

\section{Zakres kierownictwa zlecającego}

W świetle art. $5 \mathrm{~b}$ ust. 2 pkt 2 ustawy o podatku dochodowym od osób fizycznych kierownictwo zlecającego jest kierownictwem w zakresie sposobu wykonywania pracy. Z zakresu tego pojęcia ustawodawca wyłączył bowiem wyznaczanie przez zlecającego miejsca i czasu wykonywania pra$\mathrm{cy}^{18}$. Jest to analogiczna regulacja ustawowa do regulacji zawartej $\mathrm{w}$ art. 22 $\S 1$ k.p. W przepisie tym z zakresu kierownictwa pracodawcy wyłączone zostało wyznaczanie miejsca i czasu pracy ${ }^{19}$. Zakres kierownictwa zlecającego może być ujmowany szerzej niż wyznacza to art. $5 \mathrm{~b}$ ust. 2 pkt 2 ustawy o podatku dochodowym od osób fizycznych. Kierownictwo zlecającego może odnosić się nie tylko do sposobu wykonywania zleconej czynności, ale także do czasu oraz miejsca wykonywania czynności. W tym ujęciu w ramach kierownictwa zlecającego można wskazywać nie tylko sposób

${ }_{17}$ Por. J. Kurnal, Zarys teorii organizacji i zarzadzania, Warszawa 1970, s. 365.

18 Szerzej Z. Kubot, Kierownictwo pracodawcy..., s. 120-121.

19 Akcentuje to M. Gersdorf, Cechy charakterystyczne stosunku pracy po nowelizacji kodeksu pracy, „Praca i Zabezpieczenie Społeczne” 2002, nr 10, s. 19. 
wykonywania czynności, ale również wyznaczać czas i miejsce ich wykonywania. Tak rozumiane kierownictwo zlecającego jest pojęciem prawniczym szerszym od pojęcia prawnego kierownictwa zlecającego.

\section{Konkluzje}

1) Kierownictwo zlecającego stanowi właściwość niektórych stosunków zatrudnienia cywilnoprawnego oraz samozatrudnienia. Jest niezbędne w nich dla wykonywania zleconych czynności. W sposób odpowiadający potrzebom i woli zlecającego. „Nadzór i kierownictwo zatrudniającego nie jest zastrzeżone tylko dla stosunku pracy”. „W umowie zlecenia mogą wystąpić cechy kierownictwa i podporządkowania, choć nie są takie same, jak w zależności właściwej dla stosunku pracy" (art. $22 \S 1$ i $\S 1^{1}$ k.p. oraz art. 750 k.c.) ${ }^{20}$.

2) Kierownictwo zlecającego może obejmować różnorodne czynności adresowane do wykonawcy pracy. Wymienić tu należy takie czynności, jak: wskazówki, fachowe wskazówki, opinie, akceptację, zalecenia, instrukcje, sugestie, rady. Kierownictwo zlecającego może wyrażać się także w planowaniu, koordynowaniu, nadzorze, kontroli oraz przydziale pakietu zadań i podzadań w ramach projektów realizowanych przez zleceniobiorcę.

3) Kierownictwo zlecającego jest kierownictwem dotyczącym sposobu wykonania zleconych czynności, a więc kierownictwem merytorycznym. W prawniczym rozumieniu pojęcie kierownictwo zlecającego może też obejmować wyznaczanie czasu i miejsca wykonywania czynności, a przez to stawać się również kierownictwem organizacyjnym.

4) Dopuszczalność kierownictwa zlecającego w zakresie zleconych czynności znalazła wyraz w art. 5b ust. 2 pkt 2 ustawy o podatku dochodowym od osób fizycznych.

5) Kierownictwo zlecającego nie może obejmować poleceń. Pod tym względem różni się od kierownictwa pracodawcy. Wyjątek stanowią kontrakty cywilnoprawne ratowników medycznych. Wobec tej kategorii wykonawców usług podstawę kierownictwa zlecającego stanowi art. 41 ust. 1 ustawy z 8 września 2006 O Państwowym Ratownictwie Medycznym.

\section{Bibliografia}

Duraj T., Wybrane problemy pracowniczego podporzadkowania jako konstytutywnej cechy stosunku pracy, [w:] Wspótczesne problemy prawa pracy i ubezpieczeń społecznych, red. L. Florek, Ł. Pisarczyk, Warszawa 2011.

Gersdorf M., Cechy charakterystyczne stosunku pracy po nowelizacji kodeksu pracy, „Praca i Zabezpieczenie Społeczne" 2002, nr 10.

${ }^{20}$ OSNP 2014, nr 6, poz. 80. 
Guść J., O właściwości (naturze) stosunku prawnego, „Państwo i Prawo” 1997, nr 4.

Kubot Z., Kierownictwo pracodawcy, [w:] Ksztattowanie warunków pracy przez pracodawcę. Możliwości i granice, Difin, Warszawa 2011.

Kubot Z., Kierownictwo zlecającego jako pojęcie prawne, [w:] Z zagadnień współczesnego prawa pracy. Księga jubileuszowa Profesora Henryka Lewandowskiego, Warszawa 2009.

Kubot Z., Kontrakty menedżerskie średniej kadry kierowniczej, Klemar, Wrocław 1999.

Kubot Z., Nieordynatorskie systemy prowadzenia oddziatów szpitalnych, Klemar, Wrocław 2007.

Kubot Z., Zatrudnienie nauczycieli akademickich uczelni medycznej w szpitalu klinicznym jako zatrudnienie szczególne, [w:] Z aktualnych zagadnień Prawa Pracy i Zabezpieczenia Społecznego. Ksiega jubileuszowa Profesora Waleriana Sanetry, red. B. Cudowska, J. Iwulski, Tymida, Białystok 2013.

Kubot Z., T. Kuczyński, Z. Masternak, H. Szurgacz, Prawo pracy. Zarys wykładu, Warszawa 2011.

Pietrzykowski K. w: Kodeks cywilny, t. I, Komentarz do artykułów 1-44911, red. K. Pietrzykowski, wyd. 4, Warszawa 2005.

\section{The Management of the Commissioning Party in the Spheres of Civil Law Based Employment and Self-employment}

\section{Summary}

The chapter concerns the concept of the direction of the mandator in the realm of the civil law contracts and in self-employment. The author presents the legal bases of this concept and its forms. The concept of the direction of the mandator is analysed in the light of the equal position of the parties to the civil law contracts and it is compared with the competencies of the employer in this scope. 